\title{
Fed-Batch Cultivation of Saccharomyces cerevisiae in a Hyperbaric Bioreactor
}

\author{
I. Belo, R. Pinheiro, and M. Mota*
}

Centro de Engenharia Biológica-I BQF, Universidade do Minho, Campus de Gualtar, 4710-057 Braga, Portugal

\begin{abstract}
Fed-batch is the dominating mode of operation in high-cell-density cultures of Saccharomyces cerevisae in processes such as the production of baker's yeast and recombinant proteins, where the high oxygen demand of these cultures makes its supply an important and difficult task. The aim of this work was to study the use of hyperbaric air for oxygen mass transfer improvement on S. cerevisiae fed-batch cultivation. The effects of increased air pressure up to $1.5 \mathrm{MPa}$ on cell behavior were investigated. The effects of oxygen and carbon dioxide were dissociated from the effects of total pressure by the use of pure oxygen and gas mixtures enriched with $\mathrm{CO}_{2}$. Fedbatch experiments were performed in a stirred tank reactor with a $600 \mathrm{~mL}$ stainless steel vessel. An exponential feeding profile at dilution rates up to $0.1 \mathrm{~h}^{-1}$ was used in order to ensure a subcritical flux of substrate and, consequently, to prevent ethanol formation due to glucose excess. The ethanol production observed at atmospheric pressure was reduced by the bioreactor pressurization up to $1.0 \mathrm{MPa}$. The maximum biomass yield, $0.5 \mathrm{~g} \mathrm{~g}^{-1}$ (cell mass produced per mass of glucose consumed) was attained whenever pressure was increased gradually through time. This demonstrates the adaptive behavior of the cells to the hyperbaric conditions. This work proved that hyperbaric air up to $1.0 \mathrm{MPa}$ (0.2 MPa of oxygen partial pressure) could be applied to $\mathrm{S}$. cerevisiae cultivation under low glucose flux. Above that critical oxygen partial pressure value, i.e., for oxygen pressures of 0.32 and $0.5 \mathrm{MPa}$, a drastic cell growth inhibition and viability loss were observed. The increase of carbon dioxide partial pressure in the gas mixture up to $48 \mathrm{kPa}$ slightly decreased the overall cell mass yield but had negligible effects on cell viability.
\end{abstract}

\section{Introduction}

Laboratory research of microbial processes is usually performed at atmospheric pressure, but in industrial bioreactors several tens of meters high, pressure and consequently gas solubility is a function of the local position in the reactor, generally increasing by 1 bar (100 $\mathrm{kPa}$ ) for every $10 \mathrm{~m}$ increase in depth (1). Considering the heterogeneity of residence time distribution in large reactors, there will be cells growing at high pressures (at the bottom), whereas others (on top) will grow at low pressures. This could partially explain some differences in overall bioreactor performances and process productivities found between lab-scale and plant-scale microbial processes, which are particularly important for processes where dissolved gases are involved. For the case of the aerobic cultivation of the yeast $\mathrm{S}$. cer evisiae, changes in dissolved oxygen tension (DOT) cause the switch of the cells from an oxidative to a partially reductive metabolism. If the increase in the oxygen supply rate can decrease ethanol production (2), the oxygen unavailability is a problem for baker's yeast production. In fact, in this high-cell-density fed-batch process, oxygen-transfer limitation implies the reduction of the specific growth rate in order to prevent ethanol formation, and consequently the overall biomass productivity is decreased (3). Among

* To whom correspondence should be addressed. Tel: +351.253.604405. Fax: +351.253.678986. E-mail: mmota@ deb.uminho.pt. several strategies to promote oxygen mass transfer rate (OTR), the increase in power input is the most commonly used. However, excessive shearing forces cause damage to microbial cells, thus setting an upper limit to the power dissipation (4). Another common way of increasing DOT is the aeration with oxygen-enriched air $(5,6)$. However, the use of pure oxygen is generally limited to $1000 \mathrm{~L}$ bioreactor scale as a result of the cost of oxygen, unless relatively expensive biochemicals are being produced (7). The oxygen solubility in the liquid medium can also be raised by the increase of the total air pressure in the cultivation system. Bioreactor headspace pressurization has been proved to be an efficient way of OTR improvement for different microbial cell strains (8-11). However, there are limits for oxygen partial pressure rise in a cell culture due to the oxidative stress caused by oxygen (12). Thus, the establishment of these limits for industrial microbial strains is of great importance.

Carbon dioxide is involved in aerobic processes, also. Oxygen is an essential nutrient for cell respiration, whereas $\mathrm{CO}_{2}$ is a product of the cellular metabolic activity. The increase in $\mathrm{CO}_{2}$ partial pressure in the culture media due to the rise in total pressure might also have metabolic consequences to the cells (13). J ones and Greenfield (14) presented an exhaustive review on the effects of carbon dioxide on yeast growth and fermentation. The major part of the work mentioned has been performed at atmospheric pressure. Some authors have studied the effects of hyperbaric $\mathrm{CO}_{2}$ at near-critical and 
supercritical pressure values, with the purpose of applying the supercritical $\mathrm{CO}_{2}$ extraction for the ethanol recovery in the yeast fermentation process $(15,16)$. In these works, high values of $\mathrm{CO}_{2}$ pressure were used (up to $10 \mathrm{MPa}$ ).

The main goal of the present work was the application of hyperbaric air in the production of yeast cell mass. Although the fed-batch is the most commonly used mode of operation in S. cerevisiae cultivation, studies on the air, oxygen, and carbon dioxide pressure effects have been performed mostly using batch and continuous cultures (17-19).

In this work, a fed-batch cultivation of S. cerevisiae under increased pressure was studied. To identify the most significant stress factor among total air pressure and oxygen and carbon dioxide partial pressures, experiments with different gas blends were performed. Moreover, the possible existence of a cellular adaptation mechanism to hyperbaric conditions was investigated using different pressurization strategies.

\section{Materials and Methods}

Yeast Strain and Medium. The strain S. cerevisiae ATCC 32167 was used. This strain was stored at $-80^{\circ} \mathrm{C}$ in liquid medium with $20 \%$ (v/v) glycerol. From these stock cultures, agar plates ( $20 \mathrm{~g} \mathrm{~L}^{-1}$ agar) were inoculated and cells were activated by incubation overnight at 30 ${ }^{\circ} \mathrm{C}$. The liquid medium consisted of (per liter of distilled water) $5 \mathrm{~g} \mathrm{KH}_{2} \mathrm{PO}_{4}, 2 \mathrm{~g}\left(\mathrm{NH}_{4}\right)_{2} \mathrm{SO}_{4}, 0.4 \mathrm{~g} \mathrm{MgSO}_{4} \cdot 7 \mathrm{H}_{2} \mathrm{O}, 1$ $\mathrm{g}$ yeast extract, and $5 \mathrm{~g}$ glucose. The $\mathrm{pH}$ was adjusted to 4.0 prior to autoclaving. Colonies from an agar plate were used to produce the inoculum for fed-batch experiments. I nocula were grown in $200 \mathrm{~mL}$ of liquid medium, at 150 $\mathrm{rpm}$ and $30^{\circ} \mathrm{C}$, for $16 \mathrm{~h}$. Cells from this preculture were harvested by centrifugation, resuspended in $130 \mathrm{~mL}$ of fresh medium, and charged into the bioreactor.

Fed-Batch Cultivation. Fed-batch experiments were carried out in a $600 \mathrm{~mL}$ stainless steel reactor (Parr 4563) at a temperature of $30{ }^{\circ} \mathrm{C}$, stirring rate of $400 \mathrm{rpm}$, and a gas flow rate of $1 \mathrm{slpm}$. The operating pressure was set by the manipulation of the compressed gas pressure (inlet gas) and the regulatory valve position in the exit gas line. The reactor was equipped with a pressure transducer to monitor total internal pressure.

The medium used for start-up of the experiment had the same composition as the medium used for the inoculum preparation, with the exception of $2 \mathrm{~g} \mathrm{~L}^{-1}$ glucose and 4 drops of antifoam agent (Merck 7743). Since it was not possible to control the $\mathrm{pH}$ inside the bioreactor, citrate buffer $(50 \mathrm{mM})$ at $\mathrm{pH} 4.0$ and $\mathrm{pH} 5.0$ was used to prepare the medium for batch and fed-batch phase, respectively. However, the $\mathrm{pH}$ was monitored at atmospheric pressure when samples were taken. The feed medium contained per liter: $7.5 \mathrm{~g} \mathrm{KH}_{2} \mathrm{PO}_{4}, 10 \mathrm{~g}\left(\mathrm{NH}_{4}\right)_{2-}$ $\mathrm{SO}_{4}, 1 \mathrm{~g} \mathrm{MgSO}_{4} \cdot 7 \mathrm{H}_{2} \mathrm{O}, 5 \mathrm{~g}$ yeast extract, and $60 \mathrm{~g}$ glucose. F eeding was carried out to allow the volumetric cell mass concentration to increase exponentially. In the C-limited fed-batch culture without significant product formation the $C$ substrate is solely used for growth and maintenance. Hence, for a desired specific growth rate, $\mu$, and a given cell concentration, $X$, and assuming a quasisteady state for the $C$ substrate (VS = constant, where $\mathrm{V}$ is the volume and $\mathrm{S}$ the substrate concentration), the mass flow of substrate is given by the following equation $(20,21)$ :

$$
\mathrm{F}(\mathrm{t}) \mathrm{S}_{\mathrm{F}}=\frac{\mu \mathrm{XV}}{\mathrm{Y}_{\mathrm{X} / \mathrm{S}}}
$$

where $t$ is time, $F$ is the feed rate, $S_{F}$ is the substrate concentration in the feed, and $Y_{X / S}$ is the biomass/ substrate yield assumed as constant. Considering $\mu$ as time invariant the equation of the integrated cell mass balance is obtained:

$$
\mathrm{XV}=\mathrm{X}_{0} \mathrm{~V}_{0} \exp (\mu \mathrm{t})
$$

Substituting this equation into the eq 1 the expression for the exponentially increasing feeding profile is written as

$$
\mathrm{F}(\mathrm{t})=\frac{\mu \mathrm{X}_{0} \mathrm{~V}_{0} \exp (\mu \mathrm{t})}{\mathrm{S}_{\mathrm{F}} \mathrm{Y}_{\mathrm{X} / \mathrm{S}}}
$$

where $\mathrm{X}_{0}$ is the initial cell concentration in the fed-batch phase $\left(3 \mathrm{~g} \mathrm{~L}^{-1}\right)$ and $\mathrm{V}_{0}$ is the culture volume when the medium feed started $(130 \mathrm{~mL})$. The other variables assumed the following values: $S_{F}=60 \mathrm{~g} \mathrm{~L}^{-1}, Y_{X / S}=0.5$ $\mathrm{g} \mathrm{g}^{-1}$ (grams of cell dry weight per gram of glucose), and $\mu=0.1 \mathrm{~h}^{-1}$. The medium was pumped into the reactor using a high-pressure pump (J asco 880-PU) with flow rates between 1 and $25 \mathrm{~mL} \mathrm{~h}^{-1}$ according with eq 3 . The pump automatically performed the flow rate increment. In the pump program, the exponential function was approximated by a sequence of several linear functions of increasing slopes.

A constant specific gl ucose uptake rate $\left(q_{\mathrm{s}}\right)$ of $0.2 \mathrm{~g} \mathrm{~g}^{-1}$ $\mathrm{h}^{-1}$, if the cells followed a purely oxidative metabolism, was expected for the feeding fl ow profile used. The same feeding flow profile was used for all the experiments, performed at different total pressure and gas composition.

Fed-batch cultivations were carried out at constant total pressure with air, pure oxygen, and gas mixtures consisting of $21 \%(\mathrm{v} / \mathrm{v})$ oxygen, with $4 \%(\mathrm{v} / \mathrm{v})$ or $8 \%(\mathrm{v} / \mathrm{v})$ of carbon dioxide balanced with nitrogen. Experiments at constant total pressure were carried out keeping the other culture parameters unchanged. The air pressure values used are shown in Table 1. The oxygen molar flow rate was kept constant in the experiments with air, thus the total pressure rise increased the oxygen partial pressure, on one hand, and decreased the volumetric airflow rate, on the other.

To investigate separately the effects of total pressure and the effects of oxygen partial pressure, experiments were performed with pure oxygen at the same pressure values as the oxygen partial pressure values in the experiments with air. Also, the use of gas mixtures of high $\mathrm{CO}_{2}$ content enabled the dissociation of the effects of pressure and oxygen from the effects of $\mathrm{CO}_{2}$ at partial pressures up to $48 \mathrm{kPa}$. An experiment with air at gradually increasing pressure was also performed. The cultivation started at a pressure of $0.1 \mathrm{MPa}$ kept for $7 \mathrm{~h}$, followed by a pressure of $0.3 \mathrm{MPa}$ for $5 \mathrm{~h}$, and a further increase to $0.6 \mathrm{MPa}$ for the following $12 \mathrm{~h}$. Finally, pressure was maintained at 1.0 MPa till the end of the experiment (6 h).

Oxygen transfer rate was previously measured off-line by the sulfite oxidation method (22).

Samples were collected during the cultivation time to follow the cell growth, cell viability, and metabolite production (mainly ethanol).

Analytical Procedures. Cell concentration was obtained by measuring the absorbance of the suspension at $620 \mathrm{~nm}$ and converted to grams of cell dry weight per liter dividing by the calibration factor of 0.9. Glucose concentration was measured by the 3,5-dinitrosalycilic acid method (23). Ethanol and other metabolites (acetal- 
Table 1. Pressure and Composition Characteristics of Gas Used in Fed-Batch Experiments

\begin{tabular}{lccccc}
\hline \multicolumn{1}{c}{ gas $^{\mathrm{a}}$} & $\begin{array}{c}\text { total pressure } \\
(\mathrm{MPa})\end{array}$ & $\begin{array}{c}\mathrm{pO}_{2} \\
(\mathrm{MPa})\end{array}$ & $\begin{array}{c}\mathrm{pCO}_{2} \\
(\mathrm{kPa})\end{array}$ & $\begin{array}{c}\mathrm{G}_{\mathrm{O}_{2 b}} \\
(\mathrm{mmol} / \mathrm{h})\end{array}$ & $\begin{array}{c}\mathrm{Q}_{\text {gas }}{ }^{\mathrm{c}} \\
(\mathrm{L} / \mathrm{min})\end{array}$ \\
\hline air & 0.1 & 0.021 & 0.038 & 562 & 1.1 \\
air & 0.6 & 0.13 & 0.23 & 562 & 0.19 \\
air & 1.0 & 0.21 & 0.38 & 562 & 0.11 \\
air & 1.5 & 0.32 & 0.57 & 562 & 0.07 \\
oxygen & 0.13 & 0.13 & & 562 & 0.23 \\
oxygen & 0.32 & 0.32 & & 2677 & 0.35 \\
oxygen & 0.5 & 0.5 & & 2677 & 0.22 \\
mixture I & 0.6 & 0.13 & 24 & 562 & 0.19 \\
mixture II & 0.6 & 0.13 & 48 & 562 & 0.19
\end{tabular}

a Mixture I: $4 \%(\mathrm{v} / \mathrm{v}) \mathrm{CO}_{2}, 21 \% \mathrm{O}_{2}$, and $75 \% \mathrm{~N}_{2}$. Mixture II: $8 \%(\mathrm{v} / \mathrm{v}) \mathrm{CO}_{2}, 21 \% \mathrm{O}_{2}$, and $71 \% \mathrm{~N}_{2}$. Gas flow rate of $1 \mathrm{slpm}$ (standard liter per minute) was used in all experiments, except for the experiment with pure oxygen at $0.13 \mathrm{MPa}$, where a value of $0.21 \mathrm{slpm}$ was used. ${ }^{b}$ Oxygen molar flow rate fed into the bioreactor.

$\mathrm{G}_{\mathrm{O}_{2}}(\mathrm{mmol} / \mathrm{h})=\mathrm{y}_{\mathrm{O}_{2}} \cdot 1 \mathrm{slpm}$ (or $\left.0.21 \mathrm{slpm}\right)$.

$$
\begin{aligned}
& \frac{1 \mathrm{~mol}}{22.4 \mathrm{~L} \mathrm{~mol}^{-1}} \cdot \frac{60 \mathrm{~min}}{1 \mathrm{~h}} \cdot \frac{10^{3} \mathrm{mmol}}{\mathrm{mol}} \\
& \mathrm{Q}_{\text {gas }}(\mathrm{L} / \mathrm{min})=1 \mathrm{slpm}(\text { Aor } 0.21 \mathrm{slpm}) \cdot \frac{303.15 \mathrm{~K}}{273.15 \mathrm{~K}} \cdot \\
& \frac{0.1 \mathrm{MPa}}{\mathrm{P}_{\mathrm{T}}(\mathrm{MPa})} \text {, where } \mathrm{P}_{\mathrm{T}} \text { is total pressure. } \\
& \text { c Volumetric gas flow rate. }
\end{aligned}
$$

dehyde, propanol, 2,3-butanediol, ethyl acetate, and glycerol) were quantified by gas chromatography (column CP-WAX 57 CB, CHROMPACK). Cell Viability was assessed by the methylene blue staining technique (24).

\section{Results and Discussion}

Effects of Pressure on OTR and $K_{L} \mathbf{a}$. The results obtained in blank assays for the oxygen mass transfer capacity of the bioreactor at the experimental conditions are presented in Figure 1.

The increase of oxygen solubility due to the bioreactor pressurization resulted in the improvement of the oxygen absorption rate, which clearly shows the positive effects of pressure on the OTR of the system. In fact, for the sulfite concentration used $(0.3 \mathrm{M})$, there is no chemical enhancement of the mass transfer rate (25). With an air supply of constant mass flow rate, the OTR increased proportionally to the 1.3 power of oxygen solubility. Sumino et al. (26) found the same correlation between OTR and the oxygen content in the inlet gas of fermenters operating at atmospheric pressure. In the present work, the correlation was independent of the total pressure and vol umetric gas flow rate $(0.07 \mathrm{~L} / \mathrm{min}$ to 0.35 $\mathrm{L} / \mathrm{min}$ ) inside the reactor, with the exception of the experiment with air at $0.13 \mathrm{MPa}$. In this case, the airflow rate was too high, giving rise to a high value of the oxygen mass transfer coefficient $\left(\mathrm{K}_{\mathrm{L}} \mathrm{a}\right)$. High pressures can therefore be used to improve OTR, keeping $K_{L}$ a values low and without additional pure oxygen consumption.

Effects on Metabolism. Air Pressure Effects. Despite the utilization of a subcritical glucose flux in the fed-batch experiments with air at atmospheric pressure, ethanol was produced at the end of the cultivation time, probably due to oxygen limitation, since fully respi ratory metabolism was expected under conditions of sufficient culture oxygenation. The results in Figure 2 show that air at atmospheric pressure was not enough to ensure the cellular oxygen demand, since a high ethanol concentration and a low cell concentration were obtained at the end of the experiment. In fact, for the experimental

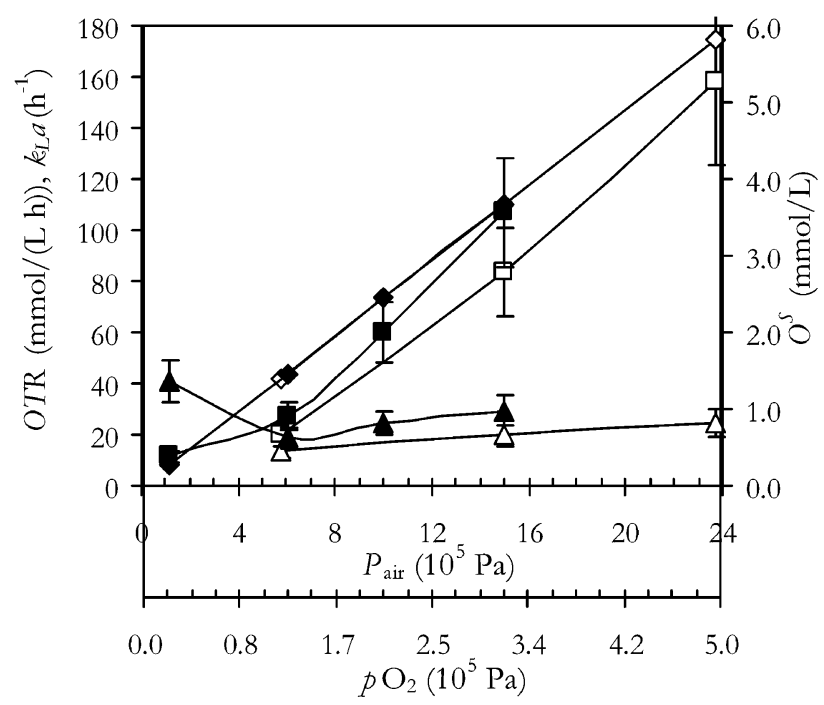

Figure 1. Effect of air pressure (closed symbols) and oxygen pressure (open symbols) on oxygen solubility, $\mathrm{O}^{\mathrm{s}}(\diamond, \diamond)$, on the maximum oxygen transfer rate, OTR $(\square, \square)$, and on the oxygen mass transfer coeficient, $\mathrm{K}_{\mathrm{L}} \mathrm{a}(\boldsymbol{\Lambda}, \Delta)$.

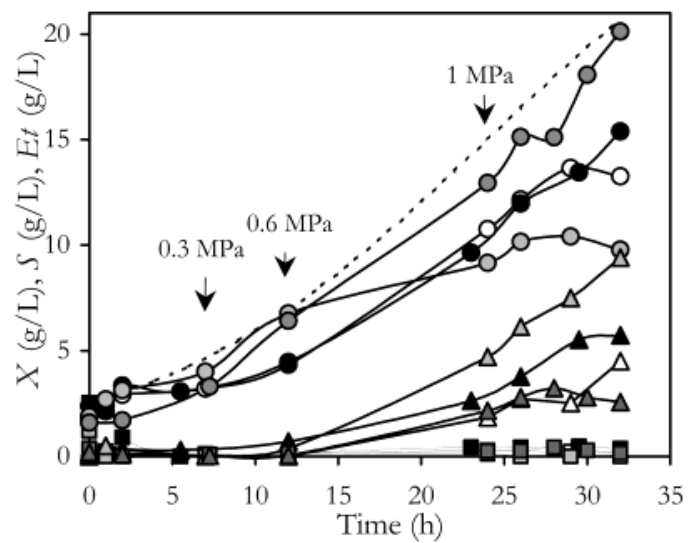

Figure 2. Time course of cell mass concentration, $X(O)$, ethanol concentration, Et $(\triangle)$, and glucose concentration, $S(\square)$, in the $\mathrm{S}$. cerevisiae fed-batch cultivation sparged with air: $0.6 \mathrm{MPa}$ (black symbols), 1.0 MPa (white symbols), $0.1 \mathrm{MPa}$ (light gray symbols) and increasing pressure from 0.1 to $1.0 \mathrm{MPa}$ (dark gray symbols). The dashed line represents the theorical time course of cell mass concentration.

conditions of stirring rate and aeration rate, at $0.1 \mathrm{MPa}$ air, the maximum value of OTR (Table 1 ) is smaller than the expected value of oxygen uptake rate (OUR) of the cells. For instance, for a specific oxygen uptake rate of 5 mmol g-1 $\mathrm{h}^{-1}(27)$, the OTR value at atmospheric pressure (12 $\mathrm{mmol} \mathrm{L}^{-1} \mathrm{~h}^{-1}$ ) is overcome by the OUR value of a culture with a cell concentration above $2.4 \mathrm{~g} \mathrm{~L}^{-1}$.

Ethanol production was significantly reduced when air pressure was raised to $0.6 \mathrm{MPa}$, but no detectable differences were found between these results and those obtained at 1.0 MPa air. However, a different behavior was observed when the experiment was carried out at increasing pressure through time. In this case, the cell density profile obtained was close to the one predicted for fully respiratory metabolism. Moreover, at $12 \mathrm{~h}$ of cultivation time, identical values of cell concentration were attained in the increasing pressure experiment (at $0.3 \mathrm{MPa}$ ) and in the 0.1 MPa experiment, whereas lower values were observed for the other experiments (at 0.6 and 1.0 MPa). This shows that S. cerevisiaecells can cope with values of pressure up to $1.0 \mathrm{MPa}$ but need an adaptation period to the hyperbaric conditions. 

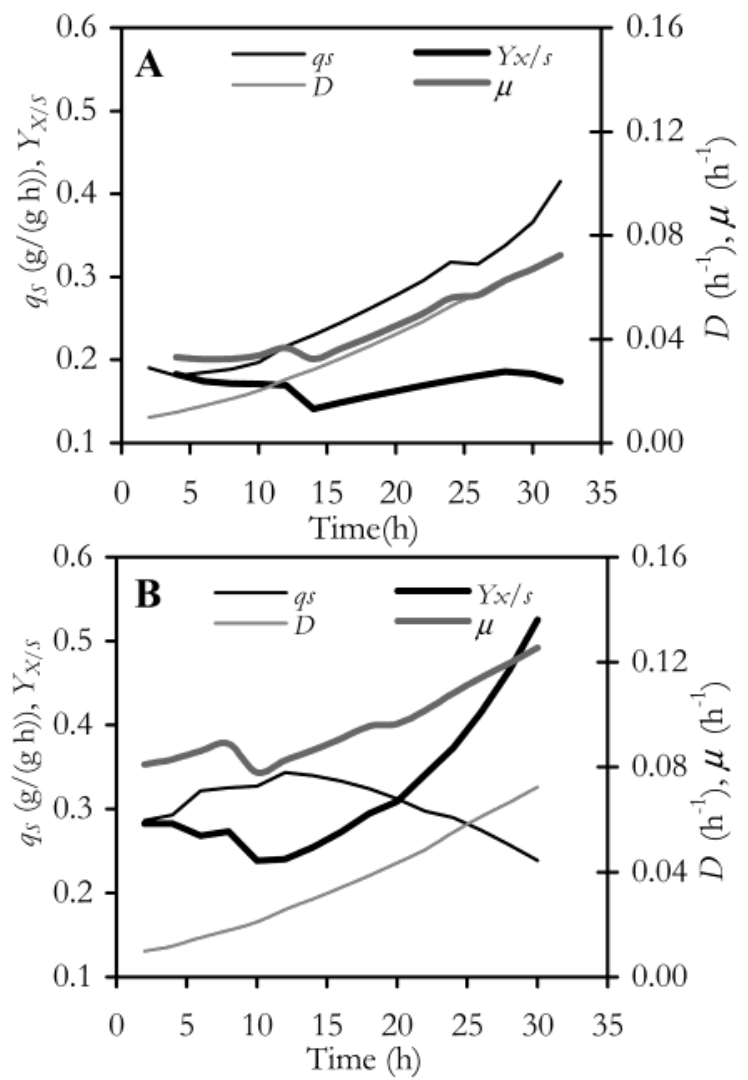

Figure 3. Time course of specific cell growth rate, $\mu$, cell mass yield, $Y_{x / s}$, specific glucose uptake rate, $q_{s}$, and dilution rate in the fed-batch cultivation experiments at atmospheric pressure (A) and at increasing pressure (B).

From the experimental data it was possibleto calculate the time course of cell mass/substrate yield $\left(\mathrm{Y}_{\mathrm{x} / \mathrm{s}}\right)$, substrate uptake rate $\left(q_{s}\right)$, specific cell growth rate $(u)$, and real dilution rate $(D)$. Figure 3 presents the results obtained for the experiments at $0.1 \mathrm{MPa}$ air (A) and at increasing pressure (B). It is clear that the gradual pressurization of the bioreactor increased specific cell growth rate and biomass yield compared with the experiment at atmospheric pressure. In this case, the decrease of cell respiration rate, due to oxygen limitation, caused a rise in the specific substrate uptake rate, which in turn increased the fermentative cell activity, thereby decreasing the biomass yield.

Overall cell mass and ethanol mass yields, as well as cell mass productivity obtained for the experiments with air are presented in Figure 4. The theoretical maximum value of cell mass yield, $0.5 \mathrm{~g} \mathrm{~g}^{-1}$ (28), was practically attained in the experiment at increasing air pressure from 0.1 to $1.0 \mathrm{MPa}$. Also, the highest cell mass productivity was found for this experiment.

From the results obtained for the experiment with air at 1.5 MPa constant pressure it is evident that this high value of air pressure imposed on the cells, without previous periods of adaptation, dramatically inhibited cellular activity. Both cell growth and ethanol production was affected by the cell exposure to an air pressure of 1.5 $\mathrm{MPa}$. In fact, in this case, cells were unable to metabolize the substrate fed to the culture and a buildup of glucose concentration was observed in the medium.

Effects of Oxygen and Carbon Dioxide Partial Pressures. The above-mentioned results show that air pressure up to $1.0 \mathrm{MPa}$, which corresponds to a $0.21 \mathrm{MPa}$ oxygen partial pressure, did not inhibit cell growth and had no effects on cell metabolism. Lower values of oxygen

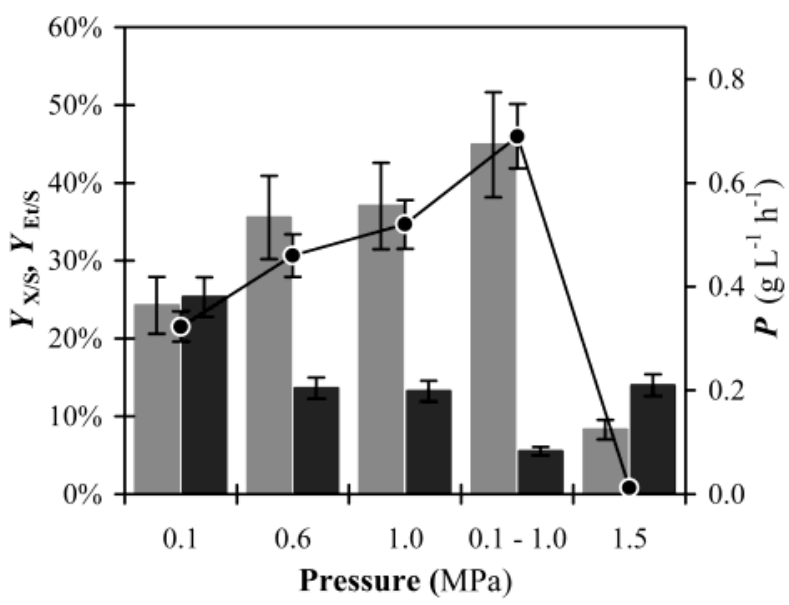

Figure 4. Effect of pressure and gas composition on the cell mass yield (grey bar), ethanol yield (black bar), and cell mass productivity $(\bullet)$ for the fed-batch cultivation of S. cerevisiaewith air.

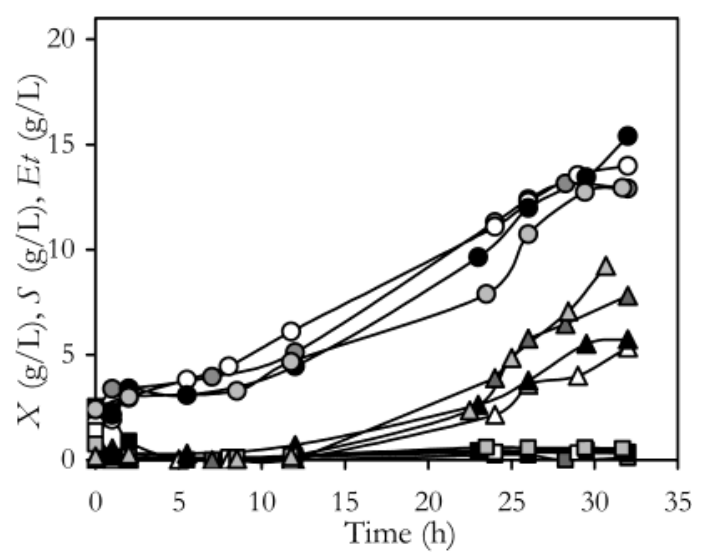

Figure 5. Time course of cell mass concentration, $X(O)$, ethanol concentration, Et $(\triangle)$, and glucose concentration, $S(\square)$, in the fed-batch cultivation of S. cerevisiae performed with air at 0.6 $\mathrm{MPa}$ of total pressure (black symbols), with pure oxygen at 0.13 MPa of total pressure (white symbols), with gas mixtures of $4 \%$ (v/v) $\mathrm{CO}_{2}, 21 \% \mathrm{O}_{2}$, and $\mathrm{N}_{2}$ (dark gray symbols), and of $8 \%(\mathrm{v} / \mathrm{v})$ $\mathrm{CO}_{2}, 21 \% \mathrm{O}_{2}$, and $\mathrm{N}_{2}$ (light gray symbols) at $0.6 \mathrm{MPa}$ of total pressure.

tension have been reported in the literature to have inhibitory effects on yeast growth at different modes of operation. In particular, Lee and Hassan (29) reported $25-40 \%$ inhibition of $\mathrm{S}$. cerevisiae cell mass yield by a $0.1 \mathrm{MPa}$ oxygen partial pressure applied to a continuous culture. In batch cultivation, a $0.08 \mathrm{MPa}$ oxygen partial pressure was indicated as cell growth inhibitor (18).

To cl early differentiate the effects of air pressure from the effects of partial oxygen and carbon dioxide pressures, experiments with pure oxygen and $\mathrm{CO}_{2}$-enriched gas mixtures were performed. Figure 5 shows the time course of cell, glucose, and ethanol concentration for fed-batch cultivation experiments performed with the same oxygen partial pressure, $0.13 \mathrm{MPa}$, using pure oxygen, as well as using air or $\mathrm{CO}_{2}$-enriched gas mixtures at a total pressure of $0.6 \mathrm{MPa}$. From the results obtained with pure oxygen at 0.13 and $0.6 \mathrm{MPa}$ air, no differences of cell behavior were found under these conditions, leading to identical overall mass yields of cell and ethanol (Figure $6)$.

The comparison of the experiments with air and pure oxygen with the experiments performed with the gas mixtures containing $4 \%(\mathrm{v} / \mathrm{v})$ and $8 \%(\mathrm{v} / \mathrm{v}) \mathrm{CO}_{2}$ at $0.6 \mathrm{MPa}$ of total pressure shows a slight deviation of the cellular 


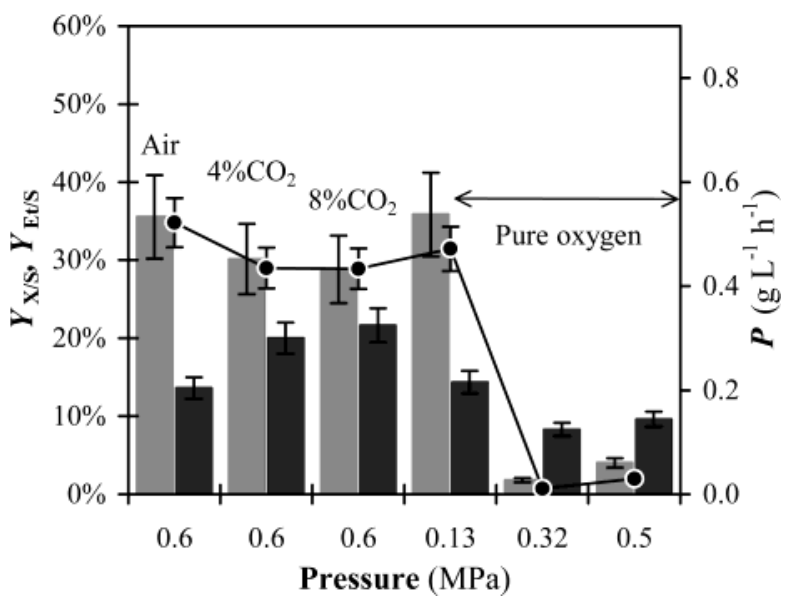

Figure 6. Effect of pressure and gas composition on the cell mass yield (gray bar), ethanol yield (black bar), and cell mass productivity (@) for the fed-batch cultivation of S. cerevisiaewith pure oxygen and gas mixtures enriched with $\mathrm{CO}_{2}$.

metabolism in the fermentative direction, due to the increase of carbon dioxide partial pressure. As can be seen in Figure 6 , the rise in carbon dioxide partial pressure to $48 \mathrm{kPa}$ decreased overall cell mass yiel $d$ and increased ethanol mass yield, leading to a slight reduction of cell mass productivity. Thus, the rise of $\mathrm{CO}_{2}$ partial pressure had detrimental effects on yeast biomass production, but opposite effects are anticipated for yeast fermentation at the values of pressure used in this work. High-pressure carbon dioxide has been proved to inhibit yeast fermentation (15), but high-pressure values (up to $7 \mathrm{MPa}$ ) of pure $\mathrm{CO}_{2}$ under anaerobic conditions were used.

The results reported here are in accordance with the observations of Kuriyama et al. (13). These authors attributed the $\mathrm{CO}_{2}$ effect to an equilibrium shift of the pyruvate dehydrogenase system toward pyruvate, since the inverse reaction produces $\mathrm{CO}_{2}$ as one of the end products. Increases in pyruvate lead to the increase in the activity of pyruvate decarboxylase. This enzyme converts pyruvate to acetal dehyde, resulting in a rise in the ethanol production rate, since the alcohol dehydrogenase equilibrium favors ethanol production. Neverthe less, it should be noted that the values of carbon dioxide content in the sparging gas were considerably higher than the values normally reported in high cell density aerobic cultures, i.e., up to $3 \%(\mathrm{v} / \mathrm{v})$ carbon dioxide in the exhaust gas (1). Thus, $\mathrm{CO}_{2}$ partial pressure inside a bioreactor at $1 \mathrm{MPa}$ would attain the maximum value of $30 \mathrm{kPa}$, which is in the range of $\mathrm{pCO}_{2}$ values tested in this work.

A limit of cell resistance to oxygen pressure exposure was found for the $S$. cerevisiae strain used in this work. From Figure 6, it is clear that the increase of oxygen pressure above $0.32 \mathrm{MPa}$ has a strong inactivation effect on the yeast. This effect is observed using either pure oxygen or air (Figure 4, air at 1.5 MPa), which indicates that the main cause of cell inhibition is the oxygen toxicity before the air total pressure.

The results of cell mass and ethanol mass global yields indicate that oxygen toxicity has a stronger effect on cell growth, i.e, on cellular respiration, than on metabolite production. The appearance of abnormal levels of metabolites other than ethanol reveals that the cell me tabolism was disturbed by hyperoxia (Table 2). Thus, high oxygen pressure affects differently the cellular mechanisms and the metabolic pathway enzymes. Be sides the probable inhibition of glucose transport mech-
Table 2. Final Concentration ( $\mathrm{mg} \mathrm{L}^{-1}$ ) of Glycerol and 2,3-Butanediola

\begin{tabular}{lcccc}
\hline & $\mathrm{O}_{2}$ & $\mathrm{O}_{2}$ & $\mathrm{O}_{2}$ & air \\
& $0.13 \mathrm{MPa}$ & $0.32 \mathrm{MPa}$ & $0.5 \mathrm{MPa}$ & $1.5 \mathrm{MPa}$ \\
\hline glycerol & 48 & 113 & 240 & 207 \\
2,3-butanediol & 124 & 284 & 366 & 167
\end{tabular}

a Average values with a $95 \%$ confidence interval of less than $10 \%$ of the average. Detection limits: $20 \mathrm{mg} \mathrm{L}^{-1}$ of glycerol and $100 \mathrm{mg} \mathrm{L}^{-1}$ of 2,3-butanediol. The values obtained for the 0.13 $\mathrm{MPa}$ oxygen pressure were similar to the values observed in the other experiments.

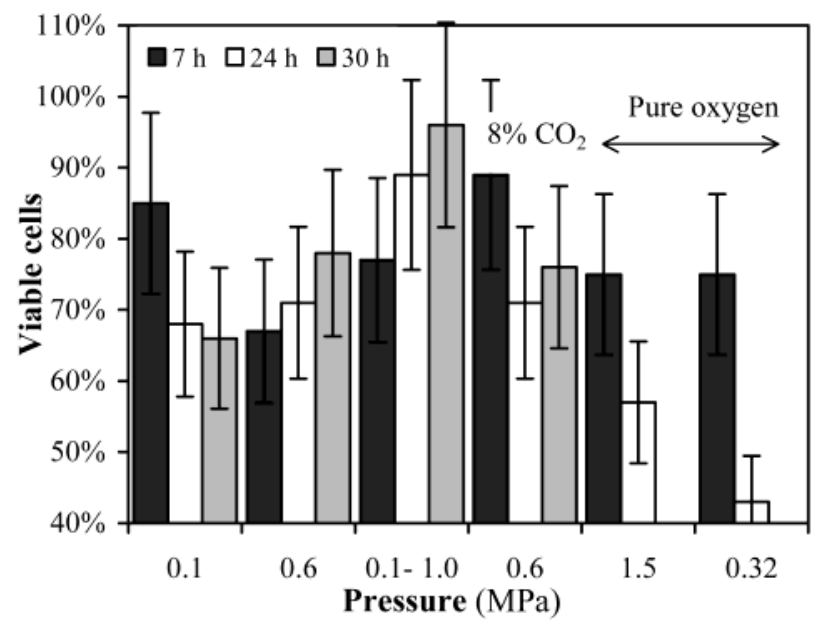

Figure 7. Effect of pressure and gas composition on viability of $\mathrm{S}$. cerevisiae cells in the fed-batch cultivation with air, gas mixture $8 \%(\mathrm{v} / \mathrm{v}) \mathrm{CO}_{2}$, and pure oxygen.

anisms across cell membrane, the respiration process was certainly one of the most affected. This is confirmed by glycerol formation, which appears as a response to the $\mathrm{NADH}$ oxidation needs of the cell that were not possible to accomplish throughout respiration (30). The appearance of 2,3-butanediol also indicates the inhibition of the enzyme alcohol dehydrogenase, which could lead to acetal dehyde accumulation inside the cell, followed by its conversion to 2,3-butanediol (13).

Effects on Cell Viability. Figure 7 represents some of the results obtained for cell viability. The air pressure rise to 1.0 M Pa had no negative effects on the fraction of viable cells. On the contrary, when pressure was increased gradually through time, cell viability was enhanced. This result confirms that hyperbaric air can be used to ensure the oxygenation of a culture and, as the viability results show, a better quality of the cell culture is obtained if cell adaptation to increased pressure is provided.

At 0.6 MPa of total pressure, no significant effects were observed on cell viability of cells cultivated under different gas composition (air or $\mathrm{CO}_{2}$-enriched gas mixture). Thus, the rise of carbon dioxide partial pressure up to $48 \mathrm{kPa}$ does not affect the cell viability of the yeast strain used in this work. Prior to the present work, Chen and Gutmanis (31) reported that a partial pressure of $\mathrm{CO}_{2}$ below $50 \mathrm{kPa}$ does not affect $\mathrm{S}$. cer evisiaeaerobic growth under atmospheric pressure.

Regarding the effects of pure oxygen on cell viability, the same results were obtained for the experiments at $0.13 \mathrm{MPa}$ of pure oxygen (data not shown) and 0.6 MPa air. This was not surprising since no metabolic changes were found when comparing the results of these two experiments. As expected, identical cell viability variation with time was also observed for the experiments using $0.32 \mathrm{MPa}$ of pure oxygen and 1.5 MPa air, but in these 
cases, a strong loss of cell viability was observed through time. Moreover, the viability decrease was more pronounced when pure oxygen was used. This confirms that oxygen toxicity and not air total pressure is the main cause of cell inactivation. Hyperoxia is a well-known cause of oxidative stress to microbial cells (32). Among others, one effect of oxidative stress is cell membrane damage due to lipid peroxidation (33). Since the method for cell viability determination used in this work was the methylene blue staining technique, which is a measure of cell membrane permeabilization, it is quite safe to state that oxidative stress was the cause of the observed cell viability loss.

\section{Conclusion}

For the experimental conditions used in this work, air pressure rise to $1.0 \mathrm{MPa}$ (10 bar) proved to be applicable to the fed-batch aerobic cultivation of Saccharomyces cerevisae strain ATCC 32167.

The difference observed in cell behavior under $0.1 \mathrm{MPa}$ constant air pressure and under an atmosphere of gradually increasing air pressure showed that cells of S. cerevisiae withstand a total air pressure up to $1.0 \mathrm{MPa}$ but need an adaptation period to the elevated pressure environment. Thus, the effects of pressure on yeast metabolism and viability depend not only on the gas composition but also on pressurization mode.

It should also be noted that this work showed that metabolic pathway enzymes are differently affected by high-pressure oxygen and carbon dioxide.

For the range of pressure values used in this study it was also possible to conclude that total air pressure is not a stress and inhibitory factor, per se, and does not present synergic effects on the inhibitory effect of oxygen and carbon dioxide on the cellular activity.

A limit for the oxygen partial pressure increase of 0.2 $\mathrm{MPa}$ was found for the operating conditions used. This is remarkably higher than the previous values reported in the literature $(1,19)$, demonstrating that the mode of operation has a strong influence on the response of this yeast strain to increased pressure. So far, no other work on the pressure effects on S. cerevisiae fed-batch aerobic cultivation is known.

In conclusion, the utilization of hyperbaric air improved the oxygen mass transfer rate from the gas phase to the culture medium, keeping $K_{L}$ a low, i.e., eliminating the need to increase the stirring and/or the aeration rates or to blend pure oxygen with the inlet air. All these aspects constitute important savings in operating costs.

\section{Notation}

D dilution rate, $\mathrm{h}^{-1}$

Et ethanol concentration, $\mathrm{g} \mathrm{L}^{-1}$

$F \quad$ volumetric feed flow rate, $L h^{-1}$

$\mathrm{K}_{\mathrm{L}} \mathrm{a} \quad$ oxygen mass transfer coefficient, $\mathrm{h}^{-1}$

$\mathrm{O}$ dissolved oxygen concentration, $\mathrm{mg} \mathrm{L}^{-1}$

OTR oxygen mass transfer rate, $\mathrm{mmol} \mathrm{h}^{-1} \mathrm{~L}^{-1}$

$P \quad$ cell mass productivity, $\mathrm{g} \mathrm{L}^{-1} \mathrm{~h}^{-1}$

qs specific substrate consumption rate, $\mathrm{g} \mathrm{g}^{-1} \mathrm{~h}^{-1}$

$\mathrm{S} \quad$ glucose concentration, $\mathrm{g} \mathrm{L}^{-1}$

slpm standard liters per minute, $\mathrm{L} \mathrm{min}^{-1}$

$\mathrm{t}$ time, $\mathrm{h}$

$\mathrm{X} \quad$ cell mass concentration, $\mathrm{g} \mathrm{L}^{-1}$

$Y_{\mathrm{Et} / \mathrm{S}} \quad$ ethanol yield, $\mathrm{g} \mathrm{g}^{-1}$

$Y_{x / S} \quad$ cell mass yield, $\mathrm{g} \mathrm{g}^{-1}$
Greek symbols

$\mu \quad$ specific growth rate, $\mathrm{h}^{-1}$

\section{References and Notes}

(1) Onken, U.; Liefke, E. Effect of total and partial pressure (oxygen and carbon dioxide) on aerobic microbial processes. In Advances in Bi ochemical Enginering/ Biotechnol ogy, Vol . 40: Bi oprocesses and E ngineering; Fiechter, A., Ed.; SpringerVerlag: Berlin, 1989; pp 137-169.

(2) Kuriyama, H.; Kobayashi, H. Effects of oxygen supply on yeast growth and metabolism in continuous fermentation. J . Ferment. Bioeng. 1993, 75, 364-367.

(3) van Hoek, P.; de Hulster, E.; van Dijken, J . P., Pronk, J . T. Fermentative capacity in high-cell-density fed-batch cultures of baker's yeast. Biotechnol. Bioeng. 2000, 68, 517-523.

(4) van Suidjam, J. C.; Metz, B. Influence of engineering variables upon the morphology of filamentous moulds. Biotechnol. Bioeng. 1981, 23, 111-148.

(5) Wecker, A.; Onken, U. Influence of dissolved oxygen concentration and shear rate on the production of pullulan by Aureobasidium pillulans. Biotechnol. Lett. 1991, 13, 155-160.

(6) Ghosh, T. K.; Bhattacharyya, B. C. Effect of inlet oxygen concentration on continuos cultivation of baker's yeast in a converging-diverging tube airlift fermentor. J . Ferment. Bioeng. 1993, 76, 153-156.

(7) White, M. D.; Glick, B. R.; Robinson, C. W. Bacterial, yeast, and fungal cultures. Effects of microorganism type and culture characteristics on bioreactor design and operation. In Bi oreactor System Design; Asenjo, J . A., Merchuk, J . C., Eds.; Marcell Dekker: New York, 1995; pp 47-87.

(8) Yang, J . D.; Wang, N. S. Oxygen mass transfer enhancement via fermentor headspace pressurization. Biotechnol. Prog. 1992, 8, 244-251.

(9) Wendlandt, K.-D.; J echorek, M., Brühl, E. The influence of pressure on the growth of methanotrophic bacteria. Acta Biotechnol. 1993, 13, 11-115.

(10) Belo, I.; Mota, M. Batch and fed-batch cultures of E. coli TB1 at different oxygen transfer rates. Effect of stirring and oxygen partial pressures on cell growth and cytochrome b5 production. Bioprocess Eng. 1998, 18, 451-455.

(11) Pinheiro, R.; Belo, I.; Mota, M. Air pressure effects on biomass yield of two different Kluyveromyces strains. Enzyme Microb. Technol. 2000, 26, 756-762.

(12) Gille, G.; Sigler, K. Oxidative stress and living cells. Folia Microbiol. 1995, 40, 131-152.

(13) Kuriyama, H.; Mahakarnchanakul, W.; Matsui, S.; Kobayashi, $\mathrm{H}$. The effects of $\mathrm{p}_{\mathrm{CO} 2}$ on yeast growth and metabolism under continuous fermentation. Biotechnol. Lett. 1993, 15, 189-194.

(14) J ones, R.; Greenfield, P. F. Effect of carbon dioxide on yeast growth and fermentation. Enzyme Microb. Technol. 1982, 4, 210-223.

(15) Thibault, J .; LeDuy, A.; Côté, F. Production of ethanol by Saccharomyces cerevisiae under high-pressure conditions. Biotechnol. Bioeng. 1987, 30, 74-80.

(16) Isenschmid, A.; Marison, I. W.; von Stockar, U. The influence of pressure and temperature of compressed $\mathrm{CO}_{2}$ on the survival of yeast cells. J . Biotechnol. 1995, 39, 229-237.

(17) Furukawa, K.; Heinzle, E.; Dunn, I.J . Influence of oxygen on the growth of Saccharomyces cerevisiae in continuous culture. Biotechnol. Bioeng. 1983, 25, 2293-2317.

(18) Abel, C.; Hübner, U.; Schügerl, K. Transient behaviour of baker's yeast during enforced periodical variation of dissolved oxygen concentration. J . Biotecnhol. 1994, 32, 45-57.

(19) Pinheiro, R.; Belo, I.; Mota, M. Physiological behaviour of Saccharomyces cerevisiae under increased air and oxygen pressures. Biotechnol. Lett. 1997, 19, 703-708.

(20) Yee, L.; Blanch, H. W. Recombinant protein expression in high cell density fed-batch cultures of Escherichia coli. Bio/ Technology 1992, 10, 1550-1556.

(21) Korz, D. L.; Rinas, U.; Hellmuth, K.; Sanders, E. A.; Deckwer, W.-D. Simple fed-batch technique for high-density cultivation of Escherichia coli. J . Biotechnol. 1995, 39, 5965. 
(22) Cooper, C. M.; Fernstrom, G. A.; Miller, S. A. Performance of agitated gas-liquid contacters. Ind. Eng. Chem. 1944, 36, 504-509.

(23) Miller, G. L. Use of dinitrosalicylic acid reagent for determination of reducing sugar. Anal. Chem. 1959, 31, 426428.

(24) J ones, R -P. Measures of yeast death and deactivation and their meaning: part I. Process Biochem. 1987, 118-128.

(25) Tribe, L. A.; Briens, C. L.; Margaritis, A. Determination of the volumetric mass transfer coefficient $\left(K_{\llcorner} a\right)$ using the dynamic "gas out-gas in" method: analysis of errors caused by dissolved oxygen probes. Biotechnol. Bioeng. 1995, 46, 388-392.

(26) Sumino, Y.; Sonoi, K.; Akiyama, S-I. Oxygen transfer rate in stirred-tank fermentors under the supply of oxygenenriched air. J . Ferment. Technol. 1992, 73, 175-177.

(27) Whoehrer, W.; Roehr, M. Regulatory aspects of baker's yeast metabolism in aerobic fed-batch cultures. Biotechnol. Bioeng. 1981, 23, 567-581.

(28) Sonnleitner, B.; Käppeli, O. Growth of Saccharomyces cerevisae is controlled by its limited respiratory capacity: formulation and verification of a hypothesis. Biotechnol. Bioeng. 1986, 28, 927-937.
(29) Lee, F.; Hassan, H. Biosyntesis of superoxide dismutase and catalase in chemostat cultures of Saccharomyces cerevisiae. Appl. Microbiol. Biotechnol. 1987, 26, 531-540.

(30) Fiechter, A.; Furhmann, G. F.; Käppeli, O. Regulation of glucose metabolism in growing yeast cells. Adv. Microb. Physiol. 1981, 2, 123-183.

(31) Chen, S. L.; Gutmanis, F. Carbon dioxide inhibition of yeast growth in biomass production. Biotechnol. Bioeng. 1976, 18, 1455-1462.

(32) Pinheiro, R.; Belo, I.; M ota, M. Oxidative stress response of Kluyeromyces marxianus to hydrogen peroxide, paraquat and pressure. Appl. Microbiol. Bi otechnol . 2002, 53, 842-847

(33) Santoro, N.; Thiele, D. J . Oxidative stress responses in the yeast Saccharomyces cerevisiae. In Yeast Stress Responses; Hohmann, S., Mager, W. H., Eds.; Springer-Verlag: Heidelberg, 1997; pp 172-211.

Accepted for publication November 22, 2002.

BP 0257067 